\title{
Transport of Resistance - Inducing Sterols in Phloem Sap of Barley ${ }^{\S}$
}

\author{
Axel T. Lehrer ${ }^{\mathrm{a}}$, Dereje Dugassa-Gobena ${ }^{\mathrm{b}}$, Stefan Vidal ${ }^{\mathrm{b}}$ and Karlheinz Seifert ${ }^{\mathrm{a}, *}$ \\ a University of Bayreuth, Organic Chemistry I/2, NW II, D-95440 Bayreuth, Germany. \\ Fax: 49-921-555358. E-mail: karlheinz.seifert@uni-bayreuth.de \\ b University of Göttingen, Institute for Entomology, Grisebachstr. 6, \\ D-37077 Göttingen, Germany \\ * Author for correspondence and reprint requests \\ Z. Naturforsch. 55c, 948-952 (2000); received July 7/August 18, 2000 \\ Hordeum vulgare, Sitobion avenae, Phloem Transport, Oxysterols
}

After root application of $\left[7 \alpha-{ }^{3} \mathrm{H}\right]-7 \beta$-hydroxysitosterol and $\left[3 \alpha, 6 \beta-{ }^{3} \mathrm{H}_{2}\right]-6 \alpha$-hydroxylathosterol these sterols could be detected in the leaves and phloem sap feeding aphids. These results imply that the phloem sap is a sterol transport system in barley plants.

\section{Introduction}

Plants are affected by a multitude of fungal diseases, which often cause high yield losses in all kinds of crops. Hofferek (1980) reported that spraying of barley plants with a root extract of barley can iduce resistance toward the fungal pathogen Puccinia striiformis West. The plasma membranes of barley roots have an exceptionally high content of free phytosterols $(57 \mathrm{~mol} \%$ of total lipids in comparison to $7 \%$ in the membranes of spinach leaves). Analysis of the sterol composition showed that sitosterol accounts for nearly two thirds of the total amount (Rochester et al., 1987). Therefore it was not surprising that the resistanceinducing compounds of barley roots could be identified as $7 \alpha$-hydroxysitosterol (1), $7 \beta$-hydroxysitosterol (2) and 7-oxositosterol (3) (Schabdach et al., 1995). These oxysterols can only be found in the roots. Stem and leaves of untreated plants have a content below detection level of GC and GC-MS coupling. Their metabolism in barley roots has also been investigated (Vesper, 1998).

Fungal resistance was induced after spraying the leaves with 7-oxysitosterols. After leaf application of $\left[3 \alpha, 7 \alpha-{ }^{2} \mathrm{H}_{2}\right]-7 \beta$-hydroxysitosterol (6) and [3 $3 \alpha-$ $\left.{ }^{2} \mathrm{H}\right]-7$-oxositosterol (7) these sterols could never be detected in the roots. After root application the two 7-oxysitosterols were found in the leaves (König and Seifert, 1998). The 7-oxysitosterols ap-

\footnotetext{
$\$$ Part 2 in the series "7-Oxysterol induced resistance towards rusts in barley".
}

plied via the roots should be transported through the xylem into leaves. The question is, whether oxysterols occur also in the phloem ? In this publication we report on the analysis of phloem sap of barley collected by means of aphids. For example, this method has been used before for the detection of the indolizidine alkaloid swainsonine in honeydew excreted by phloem selective pea aphids (Dreyer et al., 1985). Instead of collecting the phloem exsudate we have extracted and analysed the aphids. The aphid species used, Sitobion avenae Fabr., is a wide-spread herbivorous insect on grasses. It is a selective phloem feeder and commonly used for sampling pure phloem sap via the exuding stylet technique (Fisher and Frame, 1984). This practice of severing aphid stylets is often used to study phloem physiology (Barlow and McCully, 1972). In some cases other phloem-selective insects are also used, as for example leafhoppers and planthoppers on rice (Kawabe et al., 1980).

\section{Results and Discussion}

After root application of 7-oxositosterol $(\mathbf{3}, 300$ $\mu \mathrm{g} / \mathrm{ml}$ ) for 5 days the sterol could be detected by GC-MS in the roots and leaves of barley but not in the phloem sap feeding aphids. When the roots of barley plants were immersed for 2 days in a $1 \%$ aqu. ethanolic solution of $\left[3 \alpha, 7 \alpha^{2} \mathrm{H}_{2}\right]-7 \beta$-hydroxysitosterol $(6)$ or $\left[3 \alpha^{-2} \mathrm{H}\right]-7$-oxositosterol (7) (100 $\mu \mathrm{g} / \mathrm{ml}$ per compound), $0.33 \pm 0.04 \mu \mathrm{g} / \mathrm{g}$ fr. wt of 6 or $0.67 \pm 0.08 \mu \mathrm{g} / \mathrm{g}$ fr. wt of 7 were found in the leaves (König and Seifert, 1998). In the experiment with the aphids, the concentration of 7-oxosi- 
tosterol in the phloem sap was too low to detect $\mathbf{3}$ in the aphids. If the roots of barley plants were cut off and the leaves were immersed for 9 days in a $0.5 \%$ aqu. ethanolic solution of $3(300 \mu \mathrm{g} / \mathrm{ml})$, 7oxositosterol could be identified by GC-MS in the leaves and in the aphids. Since the aphids used are selective phloem feeders, 7-oxositosterol is a phloem-mobile compound.

After application of $\left[7 \alpha-{ }^{3} \mathrm{H}\right]-7 \beta$-hydroxysitosterol $(4,50 \mu \mathrm{g} / \mathrm{ml})$ and $\left[3 \alpha, 6 \beta-{ }^{3} \mathrm{H}_{2}\right]-6 \alpha$-hydroxylathosterol $(\mathbf{5}, 150 \mu \mathrm{g} / \mathrm{ml})$ the radioactivity increased in the roots $(\mathbf{4}, 47.7 \mathrm{~Bq} / \mathrm{mg}$ dry wt; $5,5432 \mathrm{~Bq} / \mathrm{mg}$ dry wt), leaves $(\mathbf{4}, 4.6 \mathrm{~Bq} / \mathrm{mg}$ dry wt; $5,267 \mathrm{~Bq} / \mathrm{mg}$ dry wt) and aphids $(\mathbf{4}, 0.25 \mathrm{~Bq} / \mathrm{mg}$ dry wt; $\mathbf{5}, 11.3$ $\mathrm{Bq} / \mathrm{mg}$ dry wt) (Table I). The concentration of $\left[3 \alpha, 7 \alpha-{ }^{2} \mathrm{H}_{2}\right]-7 \beta$-hydroxysitosterol (6) after exogenous application to the leaves was determined three days $(0.39 \pm 0.03 \mu \mathrm{g} / \mathrm{g}$ fr. wt $)$ and for weeks $(0.36 \pm 0.04 \mu \mathrm{g} / \mathrm{g}$ fr. wt) after application (König and Seifert, 1998). The concentrations indicate the absence of any metabolization and deuterium-hydrogen exchange of $\mathbf{6}$ in the leaves. Therefore it is no reason to assume that the tritium of $\left[7 \alpha^{-}{ }^{3} \mathrm{H}\right]-$ $7 \beta$-hydroxysitosterol (4) or $\left[3 \alpha, 6 \beta-{ }^{3} \mathrm{H}_{2}\right]-6 \alpha$-hydroxylathosterol (5) was completely transferred to other compounds and the detection of tritium in the aphids is based on artifacts.
The application of radiolabelled sterols can prove the downstream transport of sterols together with photosynthates. The aphids on the barley leaf surface incorporated radioactivity by feeding for 9 days (4) or 7 days (5) of the phloem sap containing the tritiated sterols $\mathbf{4}$ or $\mathbf{5}$. It is possible to calculate the amount of sterol which was absorbed by a single aphid. Aphids in the first group $(50 \mu \mathrm{g} / \mathrm{ml}$ of 4$)$ contained a mean of $0.44 \pm 0.02$ $\mathrm{ng}$ of sterol and aphids of the second group (150 $\mu \mathrm{g} / \mathrm{ml}$ of 5) contained $1.02 \pm 0.37 \mathrm{ng}$. The oxysterol concentration in the phloem sap could be estimated as follows: Unattended aphid species excrete between 20 and $40 \mathrm{nl}$ honeydew per aphid and hour (Heimbach, 1986; Völkl et al., 1999; Fischer et al., 2000). A similar honeydew production can be assumed for Sitobion avenae resulting in 480 - $960 \mathrm{nl}$ honeydew per aphid and day. Assuming a value of $720 \mathrm{nl}$ per aphid and day, an aphid of the first group fed approximately $6480 \mathrm{nl}(9$ days) and of the second group $5040 \mathrm{nl}$ (7 days). The concentrations of $\mathbf{4}$ and $\mathbf{5}$ in the phloem sap of barley seedlings should be about $68 \mathrm{ng} / \mathrm{ml}$ and $202 \mathrm{ng} / \mathrm{ml}$.

The results are very consistent considering the different sterol concentrations. Our experiments demonstrate that small amounts of oxysterols are

Table I. Radioactivity of barley plants and aphids after root application of $\left[7 \alpha-{ }^{3} \mathrm{H}\right]-7 \beta$-hydroxysitosterol (4) and $\left[3 \alpha, 6 \beta-{ }^{3} \mathrm{H}_{2}\right]-6 \alpha$-hydroxylathosterol (5).

2 independent experiments; controls: experiments without $\mathbf{4}$ and $\mathbf{5}$.

\begin{tabular}{llll}
\hline & $\begin{array}{l}\text { Radioactivity } \\
{[\mathrm{Bq} / \mathrm{mg} \text { dry wt }]}\end{array}$ & $\begin{array}{l}\text { Concentration } \\
{[\mu \mathrm{g} / \mathrm{mg} \text { dry wt }]}\end{array}$ & Number of Aphids \\
\hline Compound & & $\mathbf{4}$ & \\
Roots & 47.7 & 0.71 & \\
Leaves & 4.6 & 0.069 & 300 \\
Aphids & 0.25 & & 200 \\
Roots control & 0.005 & & \\
Leaves control & 0.002 & $\mathbf{5}$ & \\
Aphids control & 0.002 & 4.28 & 40 \\
Compound & & 0.21 & \\
Roots & 5432 & 0.0089 & \\
Leaves & 267 & & \\
Aphids & 11.3 & & \\
Roots control & 0.13 & & \\
Leaves control & 0.01 & & \\
Aphids control & 0.22 & & \\
\hline
\end{tabular}

$1 \mathrm{mg}$ dry wt of aphids $=8.38$ aphids, 4 .

$1 \mathrm{mg}$ dry wt of aphids $=8.69$ aphids, $\mathbf{5}$.

Estimated concentration of $\mathbf{4}$ in the phloem: $68 \mathrm{ng} / \mathrm{ml}$.

Estimated concentration of $\mathbf{5}$ in the phloem: $202 \mathrm{ng} / \mathrm{ml}$. 


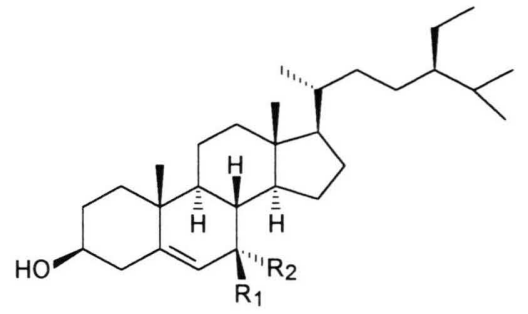

$$
\begin{array}{ll}
1 R_{1}=H & R_{2}=O H \\
2 R_{1}=O H & R_{2}=H \\
3 R_{1}, R_{2}=O & \\
4 R_{1}=O H & R_{2}=T
\end{array}
$$

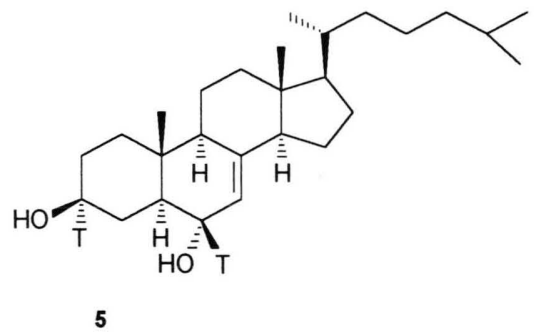

downstream transported through the phloem in barley plants. As expected, the major part of oxysterols is transported from the roots to the leaves through the xylem. This is the first time to our knowledge that 7-oxysitosterol and 6-hydroxylathosterol transport in the phloem of intact barley plants has been reported.

So far, mainly the transport of photosynthates has been followed with different methods (Orlich and Komor, 1989). The aphid technique used is doubtless one of the most precise methods for collecting phloem sap but also one of the most time consuming. Another common practice is to cut open exposed phloem vessels and collect the exudate. For example, this procedure was used for the analysis of the translocation of quinolizidine alkaloids in Lupinus albus L. (Wink and Witte, 1984). The presence of the alkaloid ricinine in the phloem sap of Ricinus communis L. seedlings has also been proven by using this technique ( $\mathrm{Hol}-$ felder et al., 1998). Cutting open vessels has always the risk of contamination with other liquids than phloem sap. The EDTA-method has been used for studies of phloem transport of tropane and pyridine alkaloids (Kitamura et al., 1993). This technique does not deliver pure phloem sap, but it is popular due to its simplicity. It is also quite unlikely to work with a substance which is very well transported in the phloem, but not at all in the xylem, as was the case with atropine in Duboisia myoporoides (Kitamura et al., 1991).

After root application of $\left[3 \alpha, 7 \alpha^{-2} \mathrm{H}_{2}\right]-7 \beta$-hydroxysitosterol (6) and $\left[3 \alpha^{2} \mathrm{H}\right]-7$-oxositosterol (7) (100 $\mu \mathrm{g} / \mathrm{ml}$ per compound) the ratio of the endogenous sterols stigmasterol and sitosterol in the barley leaves was changed to 1.71 in comparison with 0.52 in the control plants (König, 1997). Nutrient deficiency caused a similar change in the stigmasterol/ sitosterol ratio in wheat plants (Carvajal et al., 1996). Salt-stressed barley roots have a higher membrane sterol content than the controls (Brown and DuPont, 1989). Apparently, there are many factors which may alter the amount and composition of the sterols in the roots and leaves of barley and may in some cases trigger fungal resistance.

However, further activities of these sterols may also include interactions with life-history traits of herbivorous insects as well. Behmer and Grebenok (1998) were able to demonstrate that differences in the amount of definite sterols in artificial diets contributed to the survival in the diamondback moth Plutella xylostella. Moreover, the biochemical deficiency for sterol production in insects could be used in feeding experiments using the approximation of sterol uptake of aphids as calculated above to study the impact of different sterol concentrations on the preference and performance of these herbivorous species.

A study reported on different reproduction rates for aphids on different warm-season grasses, which are important transitional hosts (Kieckhefer, 1984). Interestingly, with young seedlings the differences were not so pronounced, but on mature plants there was a significant discrimination between different grasses. The same has been reported in a study comparing wheat, barley, maize and sorghum as hosts for four different aphid species (Kieckhefer and Gellner, 1988). All these studies are quite important because most aphids are vectors, which can transmit different plant viruses. Therefore, feeding deterrence can prevent a plant from getting infected with a virus. However, a virus-disease can cause stress to the plant. The consequences of that could be increased or changed sterol content, population control of insects or fungal resistance. 


\section{Experimental}

Seeds of barley (Hordeum vulgare L. cv "Mammut") were germinated on moist filter paper and after germination transferred onto perforated polystyrene plates. The seedlings were grown hydroponically in Münchener/2 solution (3 mM $\mathrm{KNO}_{3}, 2 \mathrm{~mm} \mathrm{Ca}\left(\mathrm{NO}_{3}\right)_{2}, 4 \mathrm{~mm} \mathrm{MgCl}_{2}, 0.5 \mathrm{~mm}$ $\mathrm{KH}_{2} \mathrm{PO}_{4}, \quad 0.06 \mathrm{~mm}$ EDTA-Fe(III)-Na salt, $0.023 \mathrm{~mm} \mathrm{H}_{3} \mathrm{BO}_{3}, 0.005 \mathrm{~mm} \mathrm{MnCl}, 0.4 \mu \mathrm{M} \mathrm{ZnSO}_{4}$, $0.2 \mu \mathrm{M} \mathrm{CuSO}_{4}, 0.05 \mu \mathrm{M} \mathrm{Na} \mathrm{NoO}_{4}$ ) for two weeks.

\section{Treatment with 7-oxositosterol (3)}

The nutrient solution of barley plants consisted of Münchner $/ 2$ solution containing $0.25 \%$ of detergent (Palmolive ${ }^{\circledR}$ ), $0.5 \%$ of EtOH, $300 \mu \mathrm{g} / \mathrm{ml}$ of 3 and was prepared as follows: 7-Oxositosterol (3) was dissolved in EtOH and diluted with the detergent containing Münchner/2 solution. The roots of the seedlings were placed in the Münchner/2 solution. After the nutrient solution was consumed (approximately $1 \mathrm{ml} /$ day per plant), fresh solution was added. 40 adult aphids were put on each group of 15 plants at the same day as the sterol was applied. Plants were kept in a closed insect cage for 5 days. At the end, aphids were collected, frozen in liquid $\mathrm{N}_{2}$ and dried at $60^{\circ}$ for 2 days. The barley plants were separated in rootand shoot-parts and also dried at $60^{\circ}$ for 2 days. Controls were grown in the same nutrient solution as described above but without $\mathbf{3}$.

Barley plants, grown in potting soil for two weeks, were cut off under water just above the roots. The water contained $0.01 \%$ detergent to avoid air-bubbles which could plug the xylem vessels. The shoot parts were placed in the above described Münchner/2 nutrient solution which contained $300 \mu \mathrm{g} / \mathrm{ml}$ of 3 . The level of solution was maintained constant during the whole experiment. 30 adult aphids were put on each group of 15 plants at the same day as the sterol was applied. After 9 days the experiment was finished and the aphids and barley plants were treated as described above.

Aphids and plants were ground to a fine powder with mortar and pestle and were extracted four times with $\mathrm{CHCl}_{3}$. The $\mathrm{CHCl}_{3}$ extracts were evaporated and the residues purified by TLC $(20 \times 20$ $\mathrm{cm}$ silica plates, cyclohexane/EtOAc $1: 1 \mathrm{v} / \mathrm{v})$. The bands with the $R_{f} 0.45-0.50$ were scraped off and eluted with $\mathrm{CHCl}_{3}$. The combined eluates were evaporated to dryness under reduced pressure. Samples were trimethylsilylated with N-methyl-Ntrimethylsilyltrifluoroacetamide for $12 \mathrm{~h}$ at room temp. and analysed by GC and GC-MS. 3-O-trimethylsilyl-7-oxositosterol was identified by comparison of $R_{T}$ and MS with the reference compound.

Capillary GC measurements were carried out under the following conditions: Fused silica-glass column DB1 (J\&W Scientific, $29 \mathrm{~m} \times 0.32 \mathrm{~mm}, 0.1$ $\mu \mathrm{m}$ film thickness); injector temp. $280^{\circ}$; column temp. $3 \mathrm{~min} 80^{\circ}$, heat rate $3^{\circ} \mathrm{min}^{-1}$ to $280^{\circ}$; FID temp. $290^{\circ}$; carrier gas $\mathrm{H}_{2}$, flow rate $2 \mathrm{ml} \mathrm{min}^{-1}$, split ratio 1:20. GC-MS measurements were performed on an instrument coupled to a GC fitted with a fused silica-glass column DB-5 $(30 \mathrm{~m} \times$ $0.32 \mathrm{~mm}, 0.1 \mu \mathrm{m}$ film thickness); inj. temp. $280^{\circ}$;

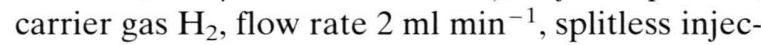
tion.

\section{3-O-Trimethylsilyl-7-oxositosterol}

$\mathrm{R}_{\mathrm{T}}$ (GC, DB1) 28.93; MS $\mathrm{m} / z$ (rel. int.): 500 $\left(\mathrm{M}^{+}, 65\right), 485$ (12), 444 (6), 410 (18), 395 (26), 281 (34), 207 (100), 129 (15).

Treatment with $\left[7 \alpha-{ }^{3} H\right]-7 \beta$-hydroxysitosterol (4) and $\left[3 \alpha, 6 \beta-{ }_{-}^{3} \mathrm{H}_{2}\right]-6 \alpha$-hydroxylathosterol (5)

The ${ }^{3} \mathrm{H}$-labelled sterols (Schröder, 1995) were purified with prep. TLC (cyclohexane-EtOAc 1:1 $\mathrm{v} / \mathrm{v}$ ). A $50 \mu \mathrm{g} / \mathrm{ml}$ solution of $\mathbf{4}$ (specific radioactivity $67 \mathrm{kBq} / \mathrm{mg}$ ) consisted of $0.5 \% \mathrm{EtOH}$ and $0.1 \%$ detergent (Palmolive ${ }^{\circledR}$ ) in Münchner/2 solution. A $150 \mu \mathrm{g} / \mathrm{ml}$ solution of $\mathbf{5}$ (specific radioactivity 1.27 $\mathrm{MBq} / \mathrm{mg}$ ) consisted of $0.5 \% \mathrm{EtOH}$ and $0.25 \%$ detergent in Münchner/2 solution. Control plants were nourished with Münchner/2 solution containing $0.5 \% \mathrm{EtOH}$ and $0.1 \%$ detergent. The roots of 2-week-old barley plants were placed in the appropriate solution, ensuring that the leaves had no contact with the solution. After the radioactive labelled sterol solution was completely consumed, fresh solution with the same unlabelled sterol in the same concentration was added (approximately $1 \mathrm{ml} /$ day per plant). This was continued until the end of the experiment (4, 9 days; 5, 7 days). Aphids and plants were harvested and dried as described above. 
Dried aphids and plant parts were weighed and wrapped in ash-free filter-paper. The samples were oxidized in a sample oxidizer which collected the total combustion water. The tritium activity was counted in a liquid scintillation counter. A Packard Sample Oxidizer Model 307 was used according to the manual with a flow setting of $18 \mathrm{ml}$ of monophase $\mathrm{S}$ and $2 \mathrm{ml}$ of permafluor $\mathrm{E} . \mathrm{N}_{2}$ and

Barlow C. A. and McCully M. E. (1972), The ruby laser as an instrument for cutting the stylets of feeding aphids. Canad. J. Zoology 50, 1497-1498.

Behmer S. T. and Grebenok, R. J. (1998), Impact of dietary sterols on life-history traits of a caterpillar. Physiol. Entomol. 23, 165-175.

Brown D. J. and DuPont F. M. (1989), Lipid composition of plasma membranes and endomembranes prepared from roots of barley. Plant Physiol. 90, 955-961.

Carvajal M., Cooke D. T. and Clarkson D. T. (1996), Responses of wheat plants to nutrient deprivation may involve the regulation of water-channel function. Planta 199, 372-381.

Dreyer D. L., Jones K. C. and Molyneux R. J. (1985), Feeding deterrency of some pyrrolizidine, indolizidine, and quinolizidine alkaloids towards pea aphids (Acyrthosiphon pisum) and evidence for phloem transport of indolizidine alkaloid swainsonine. J. Chem. Ecol. 11, 1045-1051.

Fischer M., Völkl W. and Hoffmann K. H. (2000), Interspecific variations in aphid honeydew feeding on tansy: impact of the mutualism with ants. Poster, International Congress of Entomology, 20. - 26. August 2000, Iguacu, Brasilia.

Fisher D. B. and Frame J. M. (1984), A guide to the use of the exuding-stylet technique in phloem physiology. Planta 161, 385-393.

Heimbach U. (1986), Freilanduntersuchungen zur Honigtauabgabe zweier Zierlausarten (Aphidina). J. Appl. Entomol. 101, 396-413.

Hofferek H. (1980), Oxidoreduktase-Aktivitäten und Metabolitenkonzentrationen in Gerste nach Infektion mit Puccinia striiformis West.. Biochem. Physiol. Pflanz. 175, 499-515.

Holfelder M. G. A. H., Steck M., Komor E. and Seifert K. (1998), Ricinine in phloem sap of Ricinus communis. Phytochemistry 47, 1461-1463.

Kawabe S., Fukumorita T. and Chino M. (1980), Collection of rice phloem sap from stylets of homopterous insects severed by YAG laser. Plant and Cell Physiol. 21. 1319-1327.

Kieckhefer R. W. (1984), Cereal aphid (Homoptera: Aphididae) preference for and reproduction on warmseason grasses. Environm. Entomol. 13, 888-891.

Kieckhefer R. W. and Gellner J. L. (1988), Influence of plant growth stage on cereal aphid reproduction. Crop Sci. 28, 688-690.
$\mathrm{O}_{2}$ pressure were set at 5 bar and the carburation time was $45 \mathrm{sec}$. The yield of tritiated water was determined by combustion of known standards (on filter-paper as well). The tritium content was counted with a Packard Liquid Scintillation Analyzer $2500 \mathrm{TR}$. Counting time was $10 \mathrm{~min}$, with samples kept in $30 \mathrm{ml} \mathrm{HD}-\mathrm{PE}$ scintillation tubes.

Kitamura Y., Matuo N., Takashi T. and Miura H. (1991), The characteristics of atropine transport in seedlings and regenerated plantlets of Duboisia myoporoides. J. Plant Physiol. 137, 613-618.

Kitamura Y., Yamashita R., Miura H. and Watanabe M. (1993), Phloem transport of tropane and pyridine alkaloids in Duboisia myoporoides. J. Plant Physiol. 142, $635-637$.

König M. (1997), Resistenzinduktion gegen Rostpilze bei Getreide durch oxidierte Sterole. Dissertation, University of Bayreuth, Germany.

König M. and Seifert K. (1998), Uptake and translocation of exogenously applied 7-oxysterols in barley. Phytochemistry 49, $1257-1263$.

Navari-Izzo F. and Izzo R. (1984), In vivo conversion of $\left[4-{ }^{14} \mathrm{C}\right]$ sitosterol and $\left[22,23-{ }^{3} \mathrm{H}\right]$ sitosterol to stigmasterol in barley seedlings. Phytochemistry 23, 769-772.

Orlich G. and Komor E. (1989), Methods in Enzymology, Transport in Plants, Phloem Transport. Academic Press, Inc., San Diego, New York, Berkeley, Boston, London, Sydney, Tokyo, Toronto, Vol. 174, 288-312.

Rochester C. P., Kjellbom P., Andersson B. and Larsson C. (1987), Lipid composition of plasma membranes isolated from light-grown barley (Hordeum vulgare) leaves: Identification of cerebroside as a major component. Arch. Biochem. Biophys. 255, 385-391.

Rochester C. P., Kjellbom P. and Larsson C. (1987), Lipid composition of plasma membranes from barley leaves and roots, spinach leaves and cauliflower inflorescences. Physiol. Plant. 71, 257-263.

Schabdach H., Johne S., Steiner U. and Seifert K. (1995), Plant desease resistance inducing activity of 7-oxoand 7-hydroxysterols. Z. Naturforsch. 50c, 257-262.

Schröder J. (1995), Synthese von Tritium-markierten Verbindungen des Steroidtyps. Diploma Thesis, University of Bayreuth, Germany.

Vesper T. (1998), Metabolismus, Transport und Wirkungsweise Resistenz induzierender Sterole. Dissertation, University of Bayreuth, Germany.

Völkl W., Woodring J., Fischer M., Lorenz M. W. and Hoffmann K. H. (1999), Ant-aphid mutualisms: the impact of honeydew production and honeydew sugar composition on ant preferences. Oecologia 118, 483-491.

Wink M. and Witte L. (1984), Turnover and transport of quinolizidine alkaloids. Diurnal fluctuations of lupanine in the phloem sap, leaves and fruits of Lupinus albus L. Planta 161, 519. 